\title{
Oxidative enzymes activity in sugarcane juice as a function of the planting system
}

\author{
Atividade de enzimas oxidativas em caldo de cana-de-açúcar em função do sistema de plantio
}

Tadeu Alcides MARQUES ${ }^{1 \star}$, Érick Malheiros RAMPAZO¹, Patricia Angélica Alves MARQUES²

\begin{abstract}
In Brazil, the largest producer of sugarcane in the world, the industrial process transforms this crop into ethanol and/or granulated sugar. Some cultivars exhibit enzymatic browning in the extracted sugarcane juice at levels harmful to the manufacturing process of white granulated sugar. The objective of this study was to assess the effect of sugarcane straw used as soil coverage, the use of different planting systems, and treatments with hydrogel polymer on enzymatic activity. The cultivar RB 867515 was sampled for 8 months; the first sample was obtained by cutting the upper portion of the stalk at the internode, which was taken to the laboratory for determination of the enzymatic activity of polyphenoloxidase (PPO) and peroxidase (POD). The soil coverage with different forms of straw as well as the planting systems did not change the enzymatic activity of polyphenoloxidase (PPO) and peroxidase (POD). The polyphenoloxidase (PPO) activity increased with the use of a polymer due to increased polyphenoloxidase (PPO) activity in the groove system. The enzymes studied showed changes in activity during the experimental period. The production of sugar at the end of the season (August to November) avoids the periods of highest enzymatic activity. Keywords: Saccharum; straw coverage; enzymes.
\end{abstract}

\section{Resumo}

No Brasil, o maior produtor de cana-de-açúcar do mundo, o processamento industrial transforma a cana-de-açúcar principalmente em etanol e/ou açúcar cristal. Alguns cultivares apresentam escurecimento enzimático no caldo extraído em níveis prejudiciais ao processo de fabricação do açúcar cristal branco. O objetivo da pesquisa foi avaliar o efeito do palhiço como cobertura, sistemas de plantio e tratamentos com polímero hidrogel em atividades enzimáticas. O cultivar RB 867515 foi amostrado por oito meses, retirando-se o primeiro entrenó da parte superior, que foi levado ao laboratório e procedeu-se à determinação das atividades da polifenoloxidase (PFO) e da peroxidase (POD). As coberturas do solo com diferentes formas de palhiço, bem como os sistemas de plantio, não promoveram alterações nas atividades enzimáticas das enzimas polifenoloxidase (PFO) e peroxidase (POD). A atividade da PFO foi incrementada com a utilização de polímero, este fato foi promovido pelo aumento de atividade da PFO no sistema de plantio em sulco. As enzimas estudadas apresentaram mudanças de atividades nos meses. A produção de açúcar no final da safra (agosto a novembro) evita os períodos de maiores atividades enzimáticas. Palavras-chave: Saccharum; cobertura; enzimas.

\section{Introduction}

In the first decade of the $21^{\text {st }}$ century, sugarcane production and cultivated areas grew as a result of the demand for renewable fuels, such as ethanol from sugarcane, and the international market demand for sugar, facts that contributed to price increase of this commodity (SANTOS; BORÉM; CALDAS, 2011).

The increases in production led to diverting land used for cattle ranching (low level of production) to the production of sugarcane.

Brazil is the world's largest producer of sugarcane, with 8.43 million hectares and an estimated production of 588.9 million tons in 2012, which was $5.64 \%$ lower than that of the previous harvest (2009/2010) (623.9 million tons). Brazil's Center-South region is responsible for $88.18 \%$ of the harvest in the country, and in the State of São Paulo it was estimated a production of 320.6 million tons in an area of 4.4 million hectares (COMPANHIA..., 2011).
Physical and chemical treatments are necessary in the manufacturing process of granulated sugar from sugarcane aiming to clarify the broth and produce clearer sugars, which have greater value in the market. The dark pigments in plants can be of non-enzymatic or enzymatic-origin; the latter results from the activities of oxidases present in the industrial process (REIN, 2007).

Soil moisture and temperature promotes changes in the biometrics of sugarcane by increasing the number of tillers, thus increasing the average height of the stems, and it can promote changes in sugarcane quality and quantity (BONNETT, 1998; SINGELS et al., 2005; SINGH; SHUKLA; BHATNAGAR, 2007; ALMEIDA et al., 2008).

This research hypothesis is that using different doses of hydrogel polymers, different amounts of dry matter as cover, and systems with different planting depths interferes with the

\section{Received 10/4/2012}

Accepted 30/11/2012 (005615)

${ }^{1}$ Centro de Estudos Avançados em Bioenergia e Tecnologia Sucroalcooleira, Universidade do Oeste Paulista - UNOESTE, Rod. Raposo Tavares, Km 572, CEP 19067-175, Presidente Prudente, SP, Brasil, e-mail: tmarques@uol.com.br

2 Departamento de Engenharia de Biossistemas, Instituto Nacional de Ciência e Tecnologia em Engenharia da Irrigação, Escola Superior de Agricultura "Luiz de Queiroz" ESALQ, Universidade de São Paulo - USP, Av. Pádua Dias, 11, CP 9, CEP 13418-900, Piracicaba, SP, Brasil

${ }^{*}$ Corresponding author 
physiology of plant growth promoting changes in enzyme activities. The objective of this study was to assess the effect of sugarcane straw used as soil coverage, the use of different planting systems, and treatments with hydrogel polymer on enzymatic activity.

\section{Materials and methods}

The study was conducted in the experimental area of the University of the Western São Paulo (Unoeste), campus II, in Presidente Prudente-SP, latitude $22^{\circ} 07^{\prime} 04^{\prime \prime}$ South, longitude $51^{\circ}$ $22^{\prime} 04^{\prime \prime}$ West at $430 \mathrm{~m}$ above sea level. The cultivar of sugarcane RB 867515 was planted in December 2007 and harvested in June 2009 (18 months). After harvest the first sugarcane ratoon was used in this study. The soil was identified as Red-Yellow Argisols (EMBRAPA, 1999), a type C production environment (PRADO, 2005). According to Koppen, the climate of the region is classified as Aw. The weather data such as rainfall and maximum and minimum temperature were collected during the experiment period. A composite soil sampling was performed 60 days preceding planting and soon after sugarcane harvest.

According to the recommendations of Espironelo (1992), limestone addition was not necessary to correct the soil acidity, but it was fertilized (2007 harvest season) with the equivalent of $0 \mathrm{~kg} \mathrm{ha}^{-1}$ of $\mathrm{N}, 135 \mathrm{~kg} \mathrm{ha}^{-1}$ of $\mathrm{P}_{2} \mathrm{O}_{5}$, and $135 \mathrm{~kg} \mathrm{ha}^{-1}$ of $\mathrm{K}_{2} \mathrm{O}$ using $675 \mathrm{~kg} \mathrm{ha}^{-1}$ of 20-20-00 fertilizer. In February 2008, the plants received $30.8 \mathrm{~kg} \mathrm{ha}^{-1} \mathrm{~N}$ in the form of $70 \mathrm{~kg} \mathrm{ha}^{-1}$ urea $(44 \% \mathrm{~N})$ when the average plant height was $0.20 \mathrm{~m}$,

A complete randomized block design in plot subdivided was used: block 1-planting groove system and block 2 - windrow system. Between each block, four doses of waterabsorbing polymer were tested. In these plots, the doses were subdivided into four treatments using different amounts of dry matter of sugarcane straw as coverage $(2 \times 4 \times 4)$. The enzymatic activity of polyphenoloxidase (PPO) and peroxidase (POD) was measured for eight months; apical meristem samples were collected, placed in a cooler and forwarded to the laboratory, and pressed at $250 \mathrm{kgf} \mathrm{cm}^{-2}$. The juice obtained ( $150 \mathrm{~g}$ ) was prepared according to Vanini, Kwiastokowski and Clemente (2010)

The experimental unit (sub-plot) consisted of five rows of 5 meters long and spacing of $1.5 \mathrm{~m}$ (area of $37.5 \mathrm{~m}^{2}$ ). Culms were collected monthly from March to October 2010 for juice extraction and determination of enzymatic activity, according to Campos et al. (1996). Sugarcane samples were collected in three rows ( 3 repetitions) excluding the first and the last microplot of $1 \mathrm{~m}$ in each row. The first culms, below the insertion of the TVD (Top Visible Dewlap), were collected and pressed at the laboratory. The sugarcane juice extracted was quickly analyzed.

The amounts of dry matter used were of $0 \mathrm{t} \mathrm{ha}^{-1}, 5 \mathrm{t} \mathrm{ha}^{-1}$, $10 \mathrm{t} \mathrm{ha}^{-1}, 15 \mathrm{t} \mathrm{ha}^{-1}$ used the humidity $40 \%$ on green leaves according Orlando Filho (1983), Bovi and Serra (2001) and Ripoli and Ripoli (2004). These treatments with the addition of straw started after the first harvest (June of 2009). The data were submitted to analysis of variance by the F-test at $5 \%$ probability level. The means were compared by the Scott-Knott test using the SISVAR statistical software (ANOVA, $\mathrm{p}<0.05$ ), according to Gomes (1990). For the regression analysis of enzymatic activity data, the Microcal Origin 6.0 software was used.

\section{Results and discussion}

The weather data of the rainfall, maximum, and minimum temperatures collected are shown in Figure 1. Table 1 presents the results of soil analysis carried out on the experimental soil 60 days preceding planting and soon after the harvest of sugarcane.

During the experimental period (March to October), the synthetic polymer promoted changes in the PPO activity (Table 2).

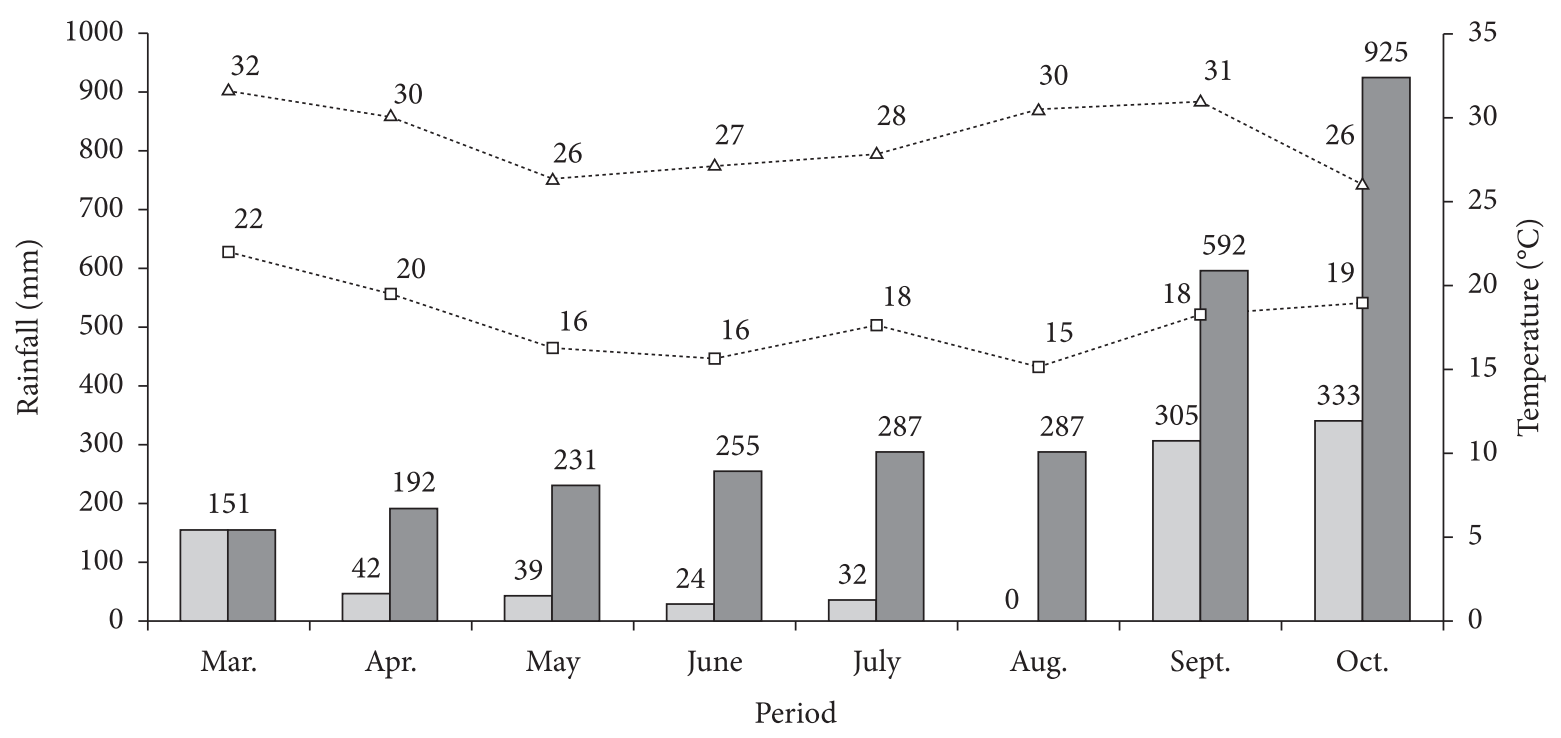

Figure 1. Weather information obtained at the meteorological station of Unoeste during the experimental period in 2010. 
Table 1. Analysis of the experimental soil before planting and after harvest of sugarcane.

\begin{tabular}{|c|c|c|c|c|c|c|}
\hline \multicolumn{7}{|c|}{ October 2007} \\
\hline $\mathrm{pH}$ in $\mathrm{CaCl}_{2}$ & $\mathrm{pH}$ in SMP & $\begin{array}{c}\text { Pot. Acidity } \\
(\mathrm{H}+\mathrm{AL})\left(\mathrm{mmolc} / \mathrm{dm}^{3}\right)\end{array}$ & $\begin{array}{c}\text { Aluminum }\left(\mathrm{Al}+{ }^{3}\right) \\
\left(\mathrm{mmolc} / \mathrm{dm}^{3}\right)\end{array}$ & $\begin{array}{l}\text { Org. Mat. } \\
\left(\mathrm{g} / \mathrm{dm}^{3}\right)\end{array}$ & $\begin{array}{l}\text { Calcium }\left(\mathrm{Ca}+{ }^{2}\right) \\
\left(\mathrm{mmolc} / \mathrm{dm}^{3}\right)\end{array}$ & $\begin{array}{l}\text { Magnesium }\left(\mathrm{Mg}^{2}\right) \\
\left(\mathrm{mmolc} / \mathrm{dm}^{3}\right)\end{array}$ \\
\hline 5.5 (Medium) & 7.3 & 11 & 0 & $\begin{array}{c}5 \\
\text { (Sandy soil) }\end{array}$ & 11 (High) & $\begin{array}{c}6 \\
\text { (Medium) }\end{array}$ \\
\hline $\begin{array}{l}\operatorname{Potassium}(\mathrm{K}+) \\
\left(\mathrm{mmolc} / \mathrm{dm}^{3}\right)\end{array}$ & $\begin{array}{l}\text { Phosphorus } \\
\left(\mathrm{mg} / \mathrm{dm}^{3}\right)\end{array}$ & $\begin{array}{l}\text { Sulphur }\left(\mathrm{SO}^{2}\right) \\
\left(\mathrm{mg} / \mathrm{dm}^{3}\right)\end{array}$ & $\begin{array}{l}\text { exchangeable } \mathrm{K}, \mathrm{Ca} \text {, and } \\
\mathrm{Mg}\left(\mathrm{mmol} / \mathrm{dm}^{3}\right)\end{array}$ & $\mathrm{Al}^{+3}$ saturation (\%) & $\begin{array}{c}\text { CEC } \\
\left(\mathrm{mmolc} / \mathrm{dm}^{3}\right)\end{array}$ & B.S(\%) \\
\hline $\begin{array}{c}1.4 \\
\text { (Bass) }\end{array}$ & $\begin{array}{c}21 \\
\text { (Medium) }\end{array}$ & $\begin{array}{c}1.3 \\
\text { (Bass) }\end{array}$ & 18 & 0 & 29 & $\begin{array}{c}63 \\
\text { (Medium) }\end{array}$ \\
\hline \multicolumn{7}{|c|}{ July 2009} \\
\hline $\mathrm{pH}$ in $\mathrm{CaCl}$ & $\mathrm{pH}$ in SMP & $\begin{array}{c}\text { Pot. Acidity } \\
(\mathrm{H}+\mathrm{AL})\left(\mathrm{mmolc} / \mathrm{dm}^{3}\right)\end{array}$ & $\begin{array}{l}\operatorname{Aluminum}\left(\mathrm{Al}+{ }^{3}\right) \\
\left(\mathrm{mmolc} / \mathrm{dm}^{3}\right)\end{array}$ & $\begin{array}{l}\text { Org. Mat. } \\
\left(\mathrm{g} / \mathrm{dm}^{3}\right)\end{array}$ & $\begin{array}{l}\text { Calcium }\left(\mathrm{Ca}+^{2}\right) \\
\left(\mathrm{mmolc} / \mathrm{dm}^{3}\right)\end{array}$ & $\begin{array}{c}\text { Magnesium }\left(\mathrm{Mg}^{2}\right) \\
\left(\mathrm{mmolc} / \mathrm{dm}^{3}\right)\end{array}$ \\
\hline 5.5 & 7.1 & 14.2 & 0 & $\begin{array}{c}7.4 \\
\text { (Sandy soil) }\end{array}$ & $\begin{array}{c}8.2 \\
\text { (High) }\end{array}$ & 3.4 \\
\hline $\begin{array}{l}\operatorname{Potassium}(\mathrm{K}+) \\
\left(\mathrm{mmolc} / \mathrm{dm}^{3}\right)\end{array}$ & $\begin{array}{l}\text { Phosphorus } \\
\left(\mathrm{mg} / \mathrm{dm}^{3}\right)\end{array}$ & $\begin{array}{l}\text { Sulphur }\left(\mathrm{SO}^{-2}\right) \\
\left(\mathrm{mg} / \mathrm{dm}^{3}\right)\end{array}$ & $\begin{array}{c}\text { exchangeable } \mathrm{K}, \mathrm{Ca} \text {, and } \\
\mathrm{Mg}\left(\mathrm{mmol} / \mathrm{dm}^{3}\right)\end{array}$ & $\mathrm{Al}^{+3}$ saturation (\%) & $\begin{array}{c}\text { CEC } \\
\left(\mathrm{mmolc} / \mathrm{dm}^{3}\right)\end{array}$ & B.S(\%) \\
\hline
\end{tabular}

Table 2. Enzymatic activity (au - activity unit) of PPO and POD in the planting systems and polymer doses

\begin{tabular}{cccc}
\hline $\begin{array}{c}\text { Quantities } \\
\left(\mathrm{kg} \mathrm{ha}^{-1}\right)\end{array}$ & Windrow & Groove & Average \\
\hline & & PPO & \\
0.00 & $210^{\mathrm{Ba}}$ & $200^{\mathrm{Ba}}$ & $200^{\mathrm{B}}$ \\
26.66 & $300^{\mathrm{Aa}}$ & $200^{\mathrm{Bb}}$ & $250^{\mathrm{A}}$ \\
53.33 & $240^{\mathrm{Ba}}$ & $260^{\mathrm{Aa}}$ & $250^{\mathrm{A}}$ \\
80.00 & $220^{\mathrm{Ba}}$ & $240^{\mathrm{Aa}}$ & $230^{\mathrm{A}}$ \\
Average & $240^{\mathrm{a}}$ & $220^{\mathrm{a}}$ & 230 \\
\hline & & POD & \\
\hline 0.00 & $760^{\mathrm{Aa}}$ & $740^{\mathrm{Aa}}$ & $750^{\mathrm{A}}$ \\
26.66 & $730^{\mathrm{Aa}}$ & $530^{\mathrm{Ba}}$ & $630^{\mathrm{A}}$ \\
53.33 & $620^{\mathrm{Aa}}$ & $790^{\mathrm{Aa}}$ & $700^{\mathrm{A}}$ \\
80.00 & $660^{\mathrm{Aa}}$ & $820^{\mathrm{Aa}}$ & $740^{\mathrm{A}}$ \\
Average & $690^{\mathrm{a}}$ & $720^{\mathrm{a}}$ & 700 \\
\hline
\end{tabular}

Uppercase letters in the same column and lowercase letters in the same row denote significant difference $(\mathrm{p}<0.05)$ by the Scott-Knott.

According to Bucheli and Robinson (1994), PPO is the enzyme with the highest activity in sugarcane juice, and Willadino et al. (2011) reported that this enzyme is related to unfavorable response mechanism factors such as water stress and can provide changes in the metabolism of plants (ZHU, 2002; FOYER; NOCTOR, 2005; CAVALCANTI et al., 2004). Some authors have observed increased PPO activity at the end of the sugarcane season (MOURA et al., 1999; BRITO et al., 2007; AZEVEDO et al., 2009). One can infer that the use of polymers changes the metabolism of plants due to the better availability of water, a fact that was detected by increasing the enzymatic activity of PPO.

No significant changes were observed in the enzymatic activity of POD (Table 2). On average, there was an increase in the enzymatic activity of PPO with the use of the polymers.

As can be seen in Table 3, the use of different doses of coverage did not promote changes in the enzymatic activity of
Table 3. Enzymatic activity (au - activity unit) of PPO and POD in the planting systems and coverage (DM - dry matter).

\begin{tabular}{cccc}
\hline $\begin{array}{c}\text { Coverage } \\
\left.(\mathrm{t} \mathrm{DM} \mathrm{ha})^{-1}\right)\end{array}$ & Windrow & Groove & Average \\
\hline 0 & & PPO & \\
5 & $230^{\mathrm{Aa}}$ & $240^{\mathrm{Aa}}$ & $230^{\mathrm{A}}$ \\
10 & $280^{\mathrm{Aa}}$ & $220^{\mathrm{Ab}}$ & $250^{\mathrm{A}}$ \\
15 & $240^{\mathrm{Aa}}$ & $220^{\mathrm{Aa}}$ & $230^{\mathrm{A}}$ \\
Average & $240^{\mathrm{Aa}}$ & $220^{\mathrm{Aa}}$ & $230^{\mathrm{A}}$ \\
& $240^{\mathrm{a}}$ & $220^{\mathrm{a}}$ & 230 \\
\hline 0 & & POD & \\
5 & $722^{\mathrm{Aa}}$ & $726^{\mathrm{Aa}}$ & $724^{\mathrm{A}}$ \\
10 & $567^{\mathrm{Aa}}$ & $646^{\mathrm{Aa}}$ & $606^{\mathrm{A}}$ \\
15 & $729^{\mathrm{Aa}}$ & $726^{\mathrm{Aa}}$ & $728^{\mathrm{A}}$ \\
Average & $732^{\mathrm{Aa}}$ & $774^{\mathrm{Aa}}$ & $753^{\mathrm{A}}$ \\
\hline
\end{tabular}

Uppercase letters in the same column and lowercase letters in the same row denote significant difference $(\mathrm{p}<0.05)$ by the Scott-Knott.

PPO and POD. This fact indicates that the plants had a weak interaction with the use of coverage, which is usually used to improve soil physical and chemical attributes such as water holding capacity and the provision of water for cultivated plants. Therefore, the polymer used, which promoted changes in the enzymatic activity, showed a stronger plant-soil relationship.

It can be observed in Figure 2 that there was a quadratic regression between the months and the PPO enzyme activities with a significant statistical adjustment at the level of $1 \%$. Deriving the equation and equalizing to zero, the curve maximization point is obtained, which in this case is 4.48 (between April and may) with 290 au activity. This enzymatic activity plays an important role in the stress that occurs during these months. Figure 1 shows rainfall reduction, which in sandy soils, promotes lower humidity in the soil leading to greater soil water stress. This fact leads to the browning of sugarcane juice, according to Qudsieh et al. (2002) and Bucheli and Robinson 


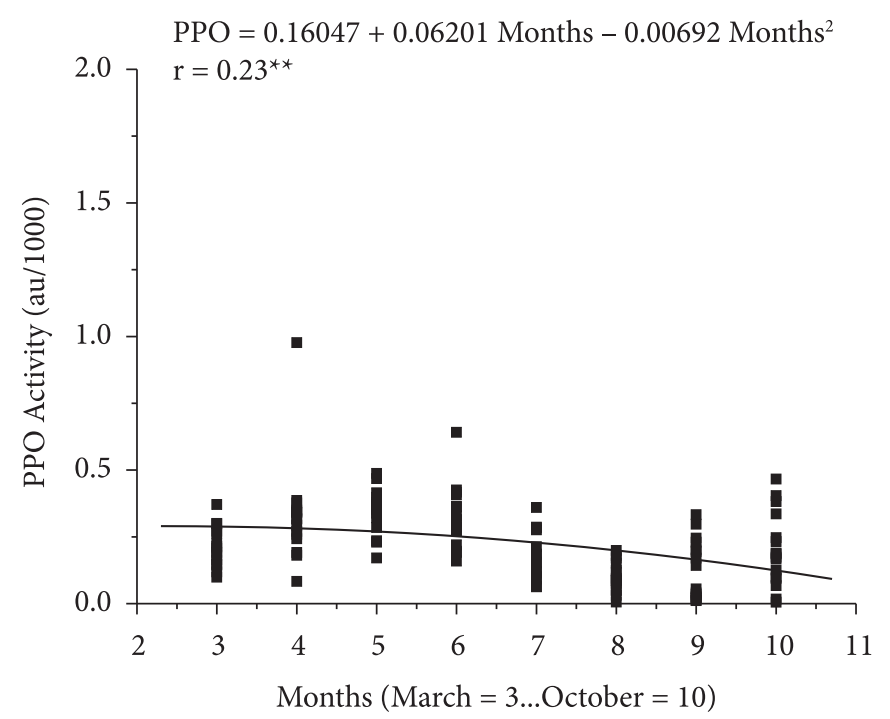

Figure 2. Enzymatic activity of PPO and POD during the study period.

(1994). For the production of whiter sugar, periods of increased enzymatic activity should be avoided, which in this study took place at the beginning of the harvest of sugarcane in the Center-South region of Brazil. In Figure 2, it can also be seen the quadratic correlation of POD activity that had its peak between June and July with the value of 1120 au; however, this enzyme has been reported to have low activity and little relationship with the browning of sugarcane juice (BUCHELI; ROBINSON, 1994).

\section{Conclusions}

The coverage used with different doses of straw $(0,5,10$, $15 \mathrm{t} \mathrm{DM} \mathrm{ha}^{-1}$ ) did not promote changes in the enzymatic activity of polyphenoloxidase (PPO) and peroxidase (POD) in the experimental period.

The planting systems studied (windrow and groove) did not promote changes in the enzymatic activity of polyphenoloxidase (PPO) and peroxidase (POD).

Polyphenoloxidase (PPO) activity, on average, increased with the use of the polymer.

The polyphenoloxidase (PPO) and peroxidase (POD) activity changed during the period of time evaluated.

Sugar production at the end of the season (August to November) avoids periods of highest enzymatic activity.

\section{Acknowledgements}

The authors acknowledge the financial support provided by CENTEC and FAPESP.

\section{References}

ALMEIDA, A. C. S. et al. Desenvolvimento vegetativo e produção de variedades de cana-de-açúcar em relação à disponibilidade hídrica e unidades térmicas. Ciência e Agrotecnologia, v. 32, n. 5, p. 1441-1448, 2008. http://dx.doi.org/10.1590/S141370542008000500013

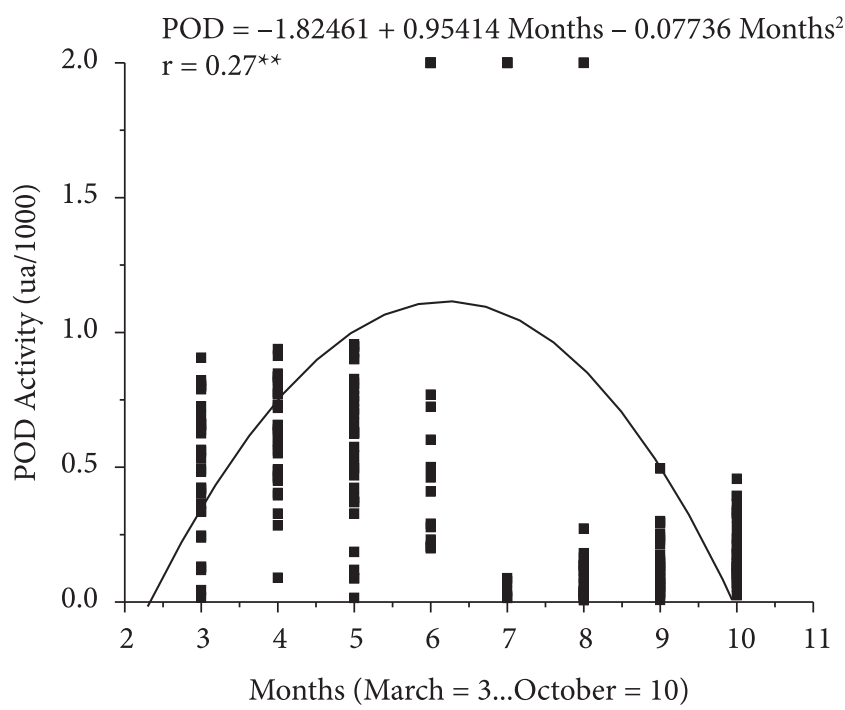

AZEVEDO, K. P. et al. Caracterização Física e enzimática em Diferentes Estágios de Desenvolvimento da Fruta de Uvaieira (Eugenia Pyriformis Cambess), Cultivada no Triângulo Mineiro. In: SEMINÁRIO INICIAÇÃO CIENTÍFICA - IFTM, 2009, Uberaba. Anais... Uberaba: IFTM, 2009.

BONNETT, G. D. Rate of leaf appearance in sugarcane, including a comparison of a range of varieties. Australian Journal Plant Physiology, v. 25, n. 7, p. 829-834, 1998. http://dx.doi.org/10.1071/ PP98041

BOVI, R.; SERRA, G. E. Folhas verdes, folhas secas, fibra do colmo e a clarificação do caldo de cana-de-açúcar. Scientia Agrícola, v. 58, n. 3, p. 457-463, jul./set. 2001. http://dx.doi.org/10.1590/S010390162001000300003

BRITO, C. A. K. et al. Abacaxi IAC Gomo-De-Mel (Ananás comosus (L.) Merrill): Características da Polpa e da Peroxidase do Suco. Boletim do CEPPA, v. 25, p. 257-266, jul./dez. 2007.

BUCHELI, C. S.; ROBINSON, S. P. Contribution of enzymatic browning to color insugarcane juice. Journal of Agricultural and Food Chemistry, v. 42, n. 2, p. 257-261, fev. 1994. http://dx.doi. org/10.1021/jf00038a006

CAMPOS, C. F. et al. Chemical composition, enzyme activity and effect of enzyme inactivation on flavor quality of green coconut water. Journal of Food Processing and Preservation, v. 20, n. 6, p. 487-500,1996. http://dx.doi.org/10.1111/j.1745-4549.1996. tb00761.x

CAVALCANTI, F. R. et al. Superoxide dismutase, catalase and peroxidase activities do not confer protection against oxidative damage in saltstressed cowpea leaves. New Phytologist, v. 163, p. 563-571, 2004. http://dx.doi.org/10.1111/j.1469-8137.2004.01139.x

COMPANHIA NACIONAL DE ABASTECIMENTO - CONAB. Cana-de-açúcar safra 2011/2012 Segundo levantamento agosto de 2011. CONAB, 2011. Disponível em: <www.conab.gov.br>. Acesso em: 05 set. 2011.

EMBRAPA. Centro Nacional de Pesquisa de Solos. Sistema brasileiro de classificação de solos. Brasília: Embrapa Produção de Informação, 1999. 412 p.

ESPIRONELO, A. Cana-de-açúcar. In: VAN RAIJ, B. et al. (Eds.) Recomendações de adubação e calagem para o Estado de São Paulo. Campinas: Instituto Agronômico, 1992. 107 p. (Boletim Técnico, n. 100). 
FOYER, C. H.; NOCTOR, G. Oxidant and antioxidant signaling in plants: a re-evaluation of the concept of oxidative stress in a physiological context. Plant, Cell \& Environment, v. 28, p. 1056, 2005. http://dx.doi.org/10.1111/j.1365-3040.2005.01327.x

GOMES, F. P. Curso de estatística experimental. Piracicaba: Nobel, 1990. $468 \mathrm{p}$.

MOURA, A. C. C. et al. Influência da Exposição ao Sol, dos Tipos de Secagem e do Armazenamento, na Atividade de peroxidase e Polifenoloxidade e Fenólicos totais em duas Cultivares e uma Linhagem de Feijão (Plaseolus vulgaris L.). Ciência e Agrotecnologia, v. 23, n. 2, p. 345-352, abr./jun. 1999.

ORLANDO FILHO, J. Nutrição e adubação da cana-de-açúcar no Brasil. Piracicaba: IAA/PLANALSUCAR. Superintendência geral, 1983. 369 p.

PRADO, H. Ambientes de produção de cana de açúcar na região centro sul do Brasil. Potafos: Piracicaba, 2005, p. 12-17.

QUDSIEH, H. Y. M. et al. Effect of maturity on chlorophyll, tannin, color and poliphenol oxidase (PPO) activity of sugarcane juice (Saccharum officinarum var. yellow cane). Journal of Agriculture and Food Chemistry, v. 50, n. 6, p. 1615-1618, 2002. PMid:11879045. http://dx.doi.org/10.1021/jf010959l

REIN, P. Cane Sugar Engineering. Berlin: VERLAG, 2007. 768 p.

RIPOLI, T. C. C.; RIPOLI, M. L. Biomassa de cana-de-açúcar: Colheita, energia e ambiente. Piracicaba, 2004. p. 302.
SANTOS, F.; BORÉM, A.; CALDAS, C. Cana-de-açúcar: Bioenergia, Açúcar e Etanol, Tecnologias e Perspectivas. 2. ed. Viçosa: UFV, 2011. 637 p.

SINGELS, A. et al. The effect of crop start date, crop class and cultivar on sugarcane canopy development and radiation interception. Field Crops Research, v. 92, n. 2-3, p. 249-260, 2005. http://dx.doi. org/10.1016/j.fcr.2005.01.028

SINGH, P. N.; SHUKLA, S. K.; BHATNAGAR, V. K. Optimizing soil moisture regime to increase water use efficiency of sugarcane (Saccharum spp. hybrid complex) in subtropical India. Agricultural Water Management, v. 90, n. 1-2, p. 95-100, 2007. http://dx.doi. org/10.1016/j.agwat.2007.02.008

VANINI, L. S.; KWIASTOKOWSKI, A.; CLEMENTE, E. Polyphenoloxidase and peroxidase in avocado pulp (Persea Americana Mill.). Ciencia e Tecnologia de Alimentos, v. 30, n. 2, p. 525-531. 2010. http://dx.doi.org/10.1590/S010120612010000200036

WILLADINO, L. et al. Estresse salino em duas variedades de cana-deaçúcar: enzimas do sistema antioxidativo e fluorescência da clorofila. Revista Ciência Agronômica, v. 42, n. 2, p. 417-422, 2011. http:// dx.doi.org/10.1590/S1806-66902011000200022

ZHU, J. K. Salt and drought stress signal transduction in plants. Annual Reviews Plant Biology, v. 53, p. 247-273, 2002. PMid:12221975 PMCid:3128348. http://dx.doi.org/10.1146/ annurev.arplant.53.091401.143329 